\title{
Post-modernism, post-structuralism, post-semiotics? Sign theory at the fin de siècle*
}

ROLAND POSNER

Abstract

The contribution describes the differences between modernism and postmodernism as historical periods of the twentieth century and establishes comparable differences between structuralism and post-structuralism as semiotic approaches. Like modernism, structuralism rejects traditional modes of thought, attempts to reconstruct academic disciplines on the basis of a few fundamental principles and strives to work with reconstructed terminologies and axioms. Like post-modernism, post-structuralism is characterized by the necessity of finding ways to continue research based on the fragmentary results left by structuralist projects. In the beginning of the twentieth century, structuralism itself had responded to materialism, atomism, historicism, and naturalism by introducing its own methodology built around the dichotomies of signified and signifier, paradigm and syntagm, synchrony and diachrony, langue and parole. Rather than rejecting this apparatus, post-structuralism explicated the paradoxes behind these dichotomies and tried to overcome them by undermining the first concept of each pair. This change of perspective foregrounded the material, processual, and intertextual character of signs as well as the sense-producing function of interpretation. Rejecting rigidly fixed methods as well as general theories, and waiving the distinction between object-signs and meta-signs in favor of their joint reflection, post-structuralist semiotics became an alternative to conventional practices of academic sign analysis and now approaches the status of an art.

Keywords: contemporary semiotics; modernism; structuralism; postmodernism; post-structuralism; semiotic methodology. 
Everyone has his disciples, but it is always Judas who writes his biography.

— English proverb

The father of deconstruction considers the statement "Deconstruction is dead" and finds it lacking.

- New York Times (January 23, 1994)

It seems the time has come to bury yet another intellectual fashion, as throughout the Western world cries ring forth from the cultural press that "Post-structuralism is dead" (Stephens 1994: 22-23). Not that all poststructuralists are dead - some are more alive than ever — nor can it be said that their appeal has waned, for no other intellectual movement unleashed more controversies in universities during the course of the 1980s than poststructuralism. Nevertheless, in the last few years the claim that structuralism has come to an end tended to be generalized so as to include the end of poststructuralism. This raises the question about the fate of semiotics. If it requires either a structuralist or a post-structuralist method, then does the demise of post-structuralism not imply the end of semiotics as well?

This is a disturbing question for semioticians, and I will respond to it by analyzing the way in which structuralism and post-structuralism are historically embedded in modernism and post-modernism. I will proceed from this by formulating a number of theses on the mutual relations of structuralist and post-structuralist semiotics, and conclude with some prospects for the future of semiotic research.

\section{Modernism and post-modernism}

The cultural history of the Western world presents itself as a sequence of approaches to the arts and sciences, where each approach called itself "modern" at the time. Carolingian illustrated script, Gothic architecture, Renaissance painting, classical French literature, German music of the Romantic period, as well as such movement as Realism, Naturalism, and Impressionism - all considered themselves "modern" (cf. Zacharias 1984: 11-15).

However, today we seem to agree that only one period of history deserves to be called "modern" (cf. Giddens 1990). The onset of the Modern Age in this sense is usually posited toward the end of the nineteenth century (cf. Davies 1982), while its full expression is said to have been reached in Bauhaus architecture, twelve-tone music, and in the literature of Proust and Gide, Kafka and Musil, Joyce and Eliot (cf. Lethen 1970; Calinescu 1987; Fokkema and Ibsch 1987; Kondylis 1991). ${ }^{1}$ As far as the sciences are concerned, the Modern Age is characterized by the extension of their field of investigation into all areas of 
life, the rationalization of methods, the specialization of researchers, the autonomy sought by the various disciples, and project-oriented interdisciplinary cooperation in large-scale research programs (cf. Knorr-Cetina 1981, 1991). Concomitantly, the economy of the Modern Age developed an increasingly radical division of labor and, whenever possible, mass production carried out on conveyor belts (Loo and van Reijen 1992).

General characteristics of the Modern Age include:

- the rejection of traditional ideas;

- the belief that all areas of life can be completely reordered on the basis of a few fundamental insights;

- the willingness to accept any temporary hardships involved in dismantling the established order with the view of a better future once the program has been completed.

When this last movement of renewal claimed the title of "modern" for itself and announced a future of permanent progress, it staked all hopes of renewal on a single card. It insisted that the chain of epochs, one following the other, had come to an end, thus taking the risk that its failure could render the very thought of continuous renewal absurd (cf. Niethammer 1989). Such a scenario, unthinkable for the proponents of modernism, occurred in the second half of the twentieth century (cf. Lyotard 1979). The ambitious ideas of the modernizers could not be upheld in the arts, nor in the sciences or in the business world (cf. Forster 1985). We find ourselves surrounded by the ruins of unfinished, grandiose experiments (cf. Kamper and van Reijen 1987) and consider it a challenge merely to come to terms with the myriad of half-completed modernist projects (cf. Gumbrecht and Weimann 1991; Guggenberger et al. 1992). In this situation, we no longer take the pathos of radical renewal in any field seriously (cf. Hassan 1987a). No present European society could be persuaded to renounce its achievements upon the simple promise that something better would take their place at some point in the future (cf. Koslowski 1987). Instead, we are satisfied with working on details, aiming at modest improvements and avoiding catastrophes.

Post-modern theorists, from Calinescu via Hassan to Welsch, always stress that no clear line can be drawn between the Modern and Post-modern ages. It can nevertheless be said that post-modern literature is less tense and ambitious, less totalitarian and mythoriented, less utopian and manifesto-like, less ideological and decisive, less hermetic and dark, less referential and representative, less stylistically pure and based in high culture than the literature of the Modern Age. Instead we find playfulness, parodies (which are often thought to criticize the canon), intertextual collages and quotations, genre metamorphosis, mixtures of everyday and high culture, multiple coding on the semantic and sociological levels (in the sense of Fiedler and Jencks), the autobiographical, the historical, the local and regional, the will to make discoveries, a tendency to be 
multicultural as well as open, insecure and unclassifiable when it comes to a world view; finally we note a wide variety of styles and opinions (Lützeler 1991: 12-13, my translation).

After the hubris and failure of modernism, it seems only logical to call this latter attitude "post-modern" (cf. Köhler 1977). Post-modernism takes up those achievements of earlier epochs which were not fully destroyed by modernism and attempts to combine them with the ruins of the Modern Age (cf. Jencks 1984; Klotz 1984; Hassan 1987b). With the failure of a permanently modern age comes the discrediting of the idea that the chain of epochs has come to an end. There will be further historical epochs even after post-modernism, but they are unlikely to be considered more "modern" than their predecessors. Other comparatives will be drawn upon to fit their claims.

\section{Structuralism}

In the humanities and in the sciences of Europe in the Modern Age, structuralism was without doubt the leading theoretical approach (cf. Albrecht 2000). Whether in the form of Ehrenfels's Gestalt psychology, Husserl's phenomenology, de Saussure's system linguistics, Mathesius's functionalism, the young Jakobson's formalism, Cassirer's philosophy of symbolic form, von Uexküll's Umwelt biology, Bühler's sematology, Mannoury's significs, Carnap's logical empirism or Hjelmslev's glossematics, ${ }^{2}$ structuralist theories were characterized by:

- the rejection of traditional modes of thought in the various academic disciplines;

- the belief that academic disciplines could be fully reconstructed on the basis of a few fundamental principles; and

- the willingness to do without established terminologies and axioms until they have been thus reconstructed.

For the first time since the philologist manifestos of the nineteenth century (cf. Stierle 1979), structuralism created a common research horizon in all humanities and social sciences (cf. Frühwald et al. 1991: 47-49). In the period between the two World Wars, it gained ground simultaneously in linguistics, psychology, sociology, anthropology, and history, as well as in the study and practice of the fine arts, literature, and music. Structuralism culminated in the idea that all these disciplines are components of an all-encompassing signbased science of culture, namely, semiotics (cf. Posner 1988, 1989). However, after World War II, and parallel with the historical experience that global designs and attempts at radical reconstruction are doomed to failure, skepticism also grew within the humanities and social sciences as to the strength of struc- 
turalist principles (cf. Todorov and Ducrot 1972: 435-453; Culler 1982: 17-30; Sless 1986: 146-160). This skepticism also had consequences for the project of a semiotic science of culture.

In light of the fact that opponents of modernism have grouped themselves under the term post-modern, it seems logical to label the opponents of structuralism post-structuralists (Schiwy 1985: 16-34; Tepe 1992). If, in addition, we accept that post-modernism links the ruins of modernism with the remaining achievements of earlier epochs, the question arises whether post-structuralism is able to mutually relate and integrate the incomplete results of structuralist science with results from other approaches (cf. Lather 1990; Keupp 1993). This question is also relevant to the perspectives of a semiotic science of culture. It can be answered by tracing the academic origins of the structuralist movement and following its development in post-structuralism.

\subsection{Starting points}

To understand the basic concepts and principles of European structuralism, we need to recall the scientific practices structuralists like Ehrenfels, de Saussure, Mathesius, and Hjelmslev were attacking (cf. Coseriu 1981: ch. 2 and 3). Research in the humanities and social sciences at the beginning of the twentieth century was characterized by:

(a) materialism, i.e., an exclusive interest in perceptible and measurable entities, joined with the belief that inductive methods, if applied to such facts, would impart relevant knowledge;

(b) atomism, i.e., the gathering and describing of facts without consideration for the contexts in which they arise;

(c) historicism, i.e., the idea that one fact gives rise to another as a result of chronological developments;

(d) naturalism, i.e., the treatment of all objects under investigation as natural objects, independent of their cultural significance.

Concerning (a): Structuralists opposed materialism with the concepts of $\mathrm{Ge}$ stalt (Ehrenfels), function (Mathesius) or form (Saussure, Bühler, Hjelmslev): "language is a form and not a substance" (Saussure 1950: 122). To the perceptible and measurable signals they ascribed a signifier (Saussure) or an expression-form (Hjelmslev), which they understood as an image (mental impression) of a signal (Saussure 1950: 122-123) or as a set of signals (Prieto 1966: 38-40). To the message content actualized in the interpreter of the signals they assigned a signified (Saussure) or a content-form (Hjelmslev), which they understood as an image of a message (Saussure 1950: 66-67) or as a set of such messages (Prieto 1966: 37-39). They replaced the naive concept of the 
sign with the idea of an expression-content pair (Hjelmslev 1963: 47-60) or a two-sided entity consisting of signifier and signified (Saussure 1950: 123).

Concerning (b): Structuralists opposed the atomist view of signs with the concepts of syntagmatic and associative relations (Saussure 1950: 122-127) or chains and paradigms (Hjelmslev 1963: 29, 39-41). In this way they distinguished between configurations of realized signs (syntagms) and configurations of virtual signs (paradigms) as two separate forms of sign structures. ${ }^{3}$

Concerning (c): Saussure (1950: 89-91) opposed historicism with the paired concepts of synchrony versus diachrony, which allowed an initially separate investigation of the interdependence of signs within syntagms and paradigms, followed by the comparative study of their occurrence at different points in history.

Concerning (d): Saussure (1950: 101-139) opposed naturalism with the paired concepts of langue (sign system, code) and parole (realization, text, discourse). This made it possible to consider each occurrence of a sign (i.e., every signal) to embody an abstract, culturally specific structure (of a code).

The Saussurean dichotomies of signifier versus signified, syntagm versus paradigm, synchrony versus diachrony, and langue versus parole formed the core of structuralist sign theory as is pointed out in synthesizing presentations such as Roland Barthes's Elements of Semiology (1968).

\subsection{Problems}

Fruitful as they proved to be in the humanities and social sciences, Saussure's dichotomies gave rise to a growing number of problems:

1. What level of existence does a langue have if it is a system of virtual signs or expression-content pairs (a code)? Does the code exist physiologically in the brain of every member of the code-community, or does it have a social existence as, say, an objective spirit, a set of common beliefs, or a system of conventions in that community?

2. What is the object of research in semiotics? Is it the code, the sign, or just perceptible signals? Saussure writes (1950: 9, 16-17) that the langue and not the parole is the true object of linguistic research. However, if the phenomena of the parole are observable, and the langue can only be inferred from these, does that not lead to the paradox of semiotics having a theoretical construct as its empirical object?

3. The coherence of the code lies in the fact that its signs determine each other on the level of both signifier and signified. Each code is a system of oppositions (differences). Thus the method of investigation for the relevant characteristics of a sign consists in the commutation of that sign with others from the 
same code (cf. Saussure 1950: 42-44; Hjelmslev 1963: 73-75; 1973: 143-145; Prieto 1966: 41-42, 62-63). This approach limits the statements that can be made about a sign to the code in which it belongs. However, can the semiosphere of a culture (cf. Lotman 2001) really be divided into such neatly separable sign systems? Is there no interaction and mutual influence of signs from different codes and different cultures?

4. Structuralism's methods of investigation involve abstracting from the variations found in the different occurrences of the signs concerned (cf. Hjelmslev 1963: 60-74). However, such abstraction dissolves the connection between synchronic variation and diachronic change, and blocks the path towards an explanation of code change. As Albrecht puts it, "the parole is not an institution and therefore has no history, despite the fact that changes in the langue are first manifested within the parole" (2000: 38, my translation). How, then, is a structuralist view of history possible?

5. For Saussure, the production and reception of signs involves the utilization of a given code. The code serves as a ready-made instrument, while the sender and recipient only act as its users (Saussure 1950: 71-73). But are the interpreters of signs really bound to their codes in this way? Are they incapable of structuring the world without participating in a code? Does the subject not enjoy a certain scope for perceiving the world and being creative outside the code?

6. Abstracting from the material qualities of a signal by assigning it to a signifier destroys the relationship between the signal and the semantic characteristics of the signified. Saussure's thesis of the arbitrariness of the sign (1950: 67-69) thus appears to be an artifact of his method. For does the variation of the signal's material qualities not expressly serve as a way for the sender to modulate his message?

7. According to Saussure, a sign's signified depends exclusively upon its opposition to other signs in the same code: "in language there are only differences without positive terms" (1950: 120; cf. Hjelmslev 1963: 45-46). Outside of the code concerned, the sign would be void of content. The range of content would thus appear to be freely structurable by each code. Yet a comparison of appropriately chosen natural languages shows that, for example, the color words of different languages may organize the spectrum of colors in various ways, but that this variation is limited: in no language are the central parts of the spectral areas of red, green, yellow, and blue subject to division through the signifieds of elementary color words (Berlin and Kay 1969). Is such material determination of the signifieds not to be found elsewhere? Does the subject of our communication, i.e., the referent, have no influence on the code used to formulate it?

8. For Saussure (1950: 122-125) and Hjelmslev (1963: 25-27), the syntagmatic relations between signifiers in sign complexes appear to be combinations 
of ready-made building blocks (Happ 1985; Harland 1993; Köster 1994). But does the co-text really have no influence on a sign's message? Is the co-text not specifically used in art, music, and literature in order to create new messages? 9. For Saussure and Hjelmslev, the signifieds of a text remain fixed even when the situational context in which it is reproduced changes (Prieto 1966: 46-47). But have we not all experienced the fact that changing contexts can change the sense of a text?

10. For Saussure, the interpretation of signs consists in the assignment of signifieds to signifiers according to a code. Interpretation is thereby reduced to a process of decoding which does not go beyond looking for the signs in that text. By means of his dyadic conception of the sign, Saussure projects the interpretation relation into the sign and gives it the status of a sign property. Can we not interpret anything outside of given signs (cf. Ogden and Richards 1923: 5, n. 2; Sless 1986: 137)? Do we not all witness signs being emptied of meaning (Even-Zohar 1983) and filled with new messages?

These doubts, among others, impaired the application of structuralist ideas in the twentieth century. The problems of (1) ontology and (2) epistemology, (3) the restrictedness of the methods, (4) the general exclusion of history and (5) of the subject, (6) the neglect of the sign's material side and (7) of the referent, the underestimation of the influence of both (8) the co-text and (9) the context on sign interpretation, plus (10) the denial of any interpretative freedom through the narrowness of Saussure's concept of the sign - all these problems gave structuralists reason to think again. Many anthropologists and linguists (cf. Sperber and Wilson 1986: 7-9) as well as psychologists (cf. Hörmann 1976; Rommetveit 1974, 1984) began to reject structuralism and to promote the creation of a pragmatic approach to sign interpretation in the sense proposed by Peirce and Morris (cf. Posner 1991; Mey 1993). Others continued to adhere to Saussure's theoretical categories but tried to open them up to new areas of application (cf. Eco 1967, 1976). They largely retained his terminology and believed the problems encountered could be solved by reinterpreting this terminology. Not least because of this maintained link to structuralism, it seems justified to label the proponents of this approach post-structuralists (Young 1981: 1).

\section{Post-structuralism}

The transition from structuralist to post-structuralist thinking was first achieved by a small number of influential authors in Paris during the 1960s. Those scholars of the humanities and social sciences who extended the domain of structuralist research beyond linguistics can be considered the forerunners of 
this development. To these belong Lévi-Strauss with his writings on anthropology and ethnology (1958), Foucault with his investigations into Europe's cultural history $(1961,1966,1969)$, Althusser with his publications on political economy (1965a, 1965b), as well as Lacan with his seminars on psychoanalysis (1966). The actual theoretical debate however took place among the contributors to the literary theory magazine $\mathrm{Tel}$ Quel, which was founded by a group of young authors in the circle around Philippe Sollers (cf. Barthes 1979) at the height of the Algerian war in 1960. Their aim was to show the world "as it is," free of ideological distortion. ${ }^{4}$ Favorite topics were the exposure of ideological fictions and the analysis of their function in society. From the mid1960s, the contributors to Tel Quel became more widely known through independent book publications. Among these were Derrida with L'écriture et la différance (1967a), De la grammatologie (1967b), and La voix et le phénomène (1967c); also Julia Kristeva with Semeiotiké: Recherches pour une sémanalyse (1969a) and Le texte du roman (1970). To these can be added Deleuze and Guattari $(1972,1976)$, who were closely linked to Foucault's work, Pêcheux (1975) and Baudrillard (1968, 1972, 1973, 1976), who continued Althusser's work, as well as Luce Irigaray (1974), who, like Kristeva, took Lacan's theories as her starting point.

The reinterpretation of Saussure's categories is most obvious in the work of Roland Barthes, who published two well-received introductions to structuralism in the journal Communications in 1964 and 1966, but then produced such books as $S / Z$ (1970) and Le plaisir du texte (1973a), which contrasted with the earlier introductions (cf. also 1973b). In 1971, Barthes gave an interview where he himself commented on this change of ideas:

In the former text [of 1966] I appealed to a general structure from which would then be derived analyses of contingent texts ... I postulated the profit there would be in reconstructing a sort of grammar of narrative, or a logic of narrative (and at that period, I believed in the possibility of such a grammar — I do not wish to deny it) . . In $S / Z$, I reversed this perspective: there I refused the idea of a model transcendent to several texts (and thus, all the more so, of a model transcendent to every text) in order to postulate ... that each text is in some sort its own model, that each text, in other words, must be treated in its difference, difference being understood precisely in a Nietzschean or a Derridean sense. (Heath, MacCabe, Christopher Prendergast 1971: 44; cf. also Young 1981: 7)

As a structuralist, Barthes had (ontologically) believed in the existence of underlying structures (codes), and had considered them (epistemologically) necessary for the explanation of sign processes: anyone not mastering the code cannot formulate a message nor understand its signals; he lacks signifier and signified as mediators in the sign process (cf. Prieto 1966). But then Barthes 
did away with such idealistic fictions: he rejected the ontological thesis of a pre-existing sign system and regarded the sign complex of the text concerned as the decisive instance. He also dispensed with the epistemological theory that a given sign is understood through a virtual sign system; Barthes allowed, at most, further discourses to count as aids to comprehension. Discourse itself became the final source of meaning, and codes were only involved when they too existed in the form of texts (as grammatical works, catechisms, fashion advertising, ordinances, and rulebooks in general).

According to Barthes, we do not have to learn rules in order to use texts, instead we practice the production of meaning directly by using existing signal complexes. Reading and writing are thus no longer understood as the encoding and decoding of meaning, but as interaction with a signal complex whose differences from other sign complexes "make sense." The idea of internalized signifieds is thus replaced by that of externally given sense. ${ }^{5}$ To show that this is possible, Barthes required Derrida's concept of writing (cf. Derrida 1967a). Writing is constantly accessible; unlike the voice, which fades away and can only be remembered, writing is not a virtual sign but manifest, and it can therefore be taken as a basis for comparison in any discourse.

All the authors named above underwent a similar change of perspective in the late 1960's. This change, which had a number of significant consequences, corresponded with a similar change of perspective that had taken place in other countries by the mid-70's. This is particularly true of Italy, where Eco, in the years between Opera aperta (1967) and A Theory of Semiotics (1976), attempted to strike a balance between Saussure's categories and Peirce's semiotic approach (cf. La struttura assente from 1968). It is true too of the former Soviet Union, where Lotman and the Tartu-Moscow School extended their text semiotics (based on a combination of Saussurean semiology and information theory) to include Bakhtin's ideas for a dialogue-oriented semiotics of culture (cf. Bakhtin 1929, 1965, 1981; Todorov 1981; Eismann and Grzybek 1994). Instead of proving the unity of literary systems characteristic of different epochs and cultures, and instead of trying to see texts as homogeneous manifestations of a single language, there was an increasing tendency to investigate the multilingualism of culture and to see each text as a heterogeneous and polystructural instrument for creating meaning (cf. Lotman 1977, 1981, 1992; Pocheptsov 1993). In the U.S., the shift away from code theory and towards the critical analysis of texts took place under the label of "Critical Theory" (cf. Culler 1981, 1982). Leaders of the change in thinking include literary theorists such as Michael Riffaterre (1978), Geoffrey Hartman (1980) and Paul de Man $(1979,1993)$, as well as philosophers such as Paul Ricoeur $(1969,1976)$ and Richard Rorty (1979). Collectively, the convergent change of perspective had far-reaching consequences for several semiotic key-notions. 


\subsection{The code}

If, in order to explain sign processes (see above: dichotomy (d), problems 1 and 2), it is no longer possible to fall back on the code, then the sign processes as such move into the foreground, and the practice of signifying in discourse (pratique signifiante, Kristeva 1969a, 1974; cf. Todorov and Ducrot 1972: 443; Barthes 1973b) becomes the object of semiotic analysis.

At the same time, de-idealized code-like concepts were taking on a more central role in the analysis of different areas of culture. Foucault $(1966,1969)$ reconstructed the set of common beliefs in a society as an epistemé; Althusser (1970) tried to locate the ideology within the "power structures" of a state; Baudrillard $(1968,1972,1976)$ considered schemata of political behavior as complexes of simulacra; Lyotard (1979) conceived of the universal designs of theorists as "grand narratives." Even if the ontological and epistemological preconditions of code theory were no longer taken seriously, it was felt that code-like constellations were all around us, and the manipulation connected with them was to be fought against politically. One example is Baudrillard's claims about late capitalist society (1973): More and more areas of life are measured in terms of money. Profit-oriented codification not only structures the world of work, but has also infiltrated leisure time and determines the life of children and the retired as well as relations between the sexes. Not only the exchange of material goods, but also that of knowledge is increasingly schematized and automatized, i.e., encoded with respect to maximizing profits. The most effective instruments of this process are the mass media. Individuals in developed capitalist societies are controlled much more effectively by this semiotic spoon-feeding than by economic exploitation in the style of the nineteenth century.

What is important here is the revolution which Barthes's change of perspective allows in the semiotic analysis of these developments. For whoever analyzed the spoon-feeding practices as such and presented them as codes in the established manner was, like it or not, making such practices all the more accessible to the manipulators and becoming himself an accomplice to this manipulation (cf. Schiwy 1985: 19-20). To contrast this, the post-structuralists want scholars to do everything to prevent the grasping of power by means of codification processes. The new semiotics thus has the task of shattering the code-fictions of the ruling elite. It can do this all the more effectively with the belief that sign processes are possible without codes.

\subsection{The signifier}

All classical definitions of the sign relied on the balancing of its two sides (see above: dichotomy (a), problem 3). Following the de-ideologizing of the 
signified, the scales now tip in favor of the signifier, which is seen as the ontological and epistemological basis of everything else (Todorov and Ducrot 1972: 438).

\subsection{The signified}

The close relationship of signifier and signified postulated by Saussure and Hjelmslev (see above: dichotomy (a), problems 3, 9 and 10) is dissolved. The signified is no longer envisioned as an entity in its own right, located somewhere in the brain or mind. Instead it is assimilated to the signifier following the theories of Peirce (cf. Lacan 1966; Todorov and Ducrot 1972: 439-442). Just as Peirce believed each sign process to be characterized by the fact that its interpretant may emerge as the representamen of a new sign process,${ }^{6}$ so too does Lacan consider each signifier to be a potential trigger for the production of a further signifier. Instead of a signified, Lacan and the other post-structuralists assume an endless chain of signifiers.

\subsection{The signal}

If the code as a pre-existing virtual sign system is discredited, then likewise the signifier of a sign cannot precede the discourse as a virtual unit. Rather, it is the result of a comparison with other signifiers (see above: dichotomy (d), problems 4 and 6). The difference between the semiotically relevant characteristics of a signal and its further material properties is not established in advance. This widens the interpreter's view to the unlimited number of properties the signal may have, each one a potential trace of a signified. The material nature of a sign again becomes the focus of interest (Gumbrecht 1988: 915; SchliebenLange 1993). It becomes the starting point of the practice of signifying (pratique signifiante). As the latter is a creative process rather than a blind course of events, there is no reason to confuse the concentration on the material nature of a sign with the mechanistic materialism of the nineteenth century (Todorov and Ducrot 1972: 451).

\subsection{The discourse}

With the help of commutation tests, Saussure and Hjelmslev extracted the code from discourse in the form of a system of oppositions (differences) between virtual signs (dichotomy (d), problem 3). If, suspecting false ideology, one dispenses with the concept of codes altogether, then the understanding of dis- 
course needs to be analyzed as the direct result of processes of differentiation. This not only involved differences between the signifiers linked in a syntagm, but also - unlike Saussure's version - differences between signifier and signified, where the latter is conceived as a chain of further potential signifiers (see point 3.3 above). A static system of differences between virtual signs in a code is thus replaced by a dynamic interplay of differences within discourse. Foucault (1969) goes so far as to consider discourse no longer a sign complex, but a set of practices which pattern the object of that discourse.

\subsection{The context}

If the interplay of differences is to be sought directly within discourse, then we need not limit ourselves to differences between syntagmatically linked signifers nor between signifiers and signifieds, i.e., signifiers of other discourses (see above: dichotomy (b), problems 7 and 8). The difference between that discourse's signifiers and further situational circumstances may also be drawn upon. After all, this is what makes the signs in a discourse recognizable as such and gives them meaning. If the sign is not ephemeral (as in acoustic communication), but enjoys permanent presence (like writing), then even the context may become subject to change. This allows for the emergence of new differences and is a basis for the further generation of sense (cf. de Man 1979).

\subsection{The reading process}

Instead of assuming a discourse contains a fixed content even before its reception (in the form of a complex signified which merely requires decoding; see above: dichotomies (b) and (d), problems 3 and 5), post-structuralist semiotics focuses on the interplay of differences among signifiers as well as between the discourse and its changing contexts. The reading process thus consists in taking up these differences and in making sense through the production of additional differences. Put simply, the purpose is no longer the search for a prefabricated message, but the creation of sense. In an extreme case, the discourse may consist in an utterance void of content, which the recipient reorganizes in line with new contexts. Moreover, every discourse may be subject to numerous readings; "its meaning" - if such a term is to be allowed at all — no longer consists of what the sender intends (which is a result of only one out of many readings) but in the results of all possible readings; this, however, can never be specified since further readings will always be possible. On the social level (see point 3.1 above), the reading process does not attempt decoding, but rather the interpreter's emancipation from code-fictions, that is, "de-codification." 


\subsection{The intertext}

One particular type of context which may influence the reading of a discourse consists of previous discourses. By comparing text fragments from other discourses (see above: dichotomies (b) and (c), problems 4 and 8), we may perceive specific differences which help to identify the historical position of the present discourse: "We call intertextuality that interaction between texts which occurs within a single text. For the expert, intertextuality is a notion which indicates the way a text reads history and inserts itself in history" (Kristeva 1969b: 443, my translation). Even for the tracing of intertextual references it is of secondary importance whether the sender had these other texts in mind when producing the discourse. Furthermore, the reading of a discourse with a view to its intertextual references turns the text as a tool of the sender into one with which the recipient can create meaning. The intertextual references in particular serve to divide the given discourse into components and to create a network of links between them which are subject to hierarchies of attention that change according to the part of the text being read at the time. In terms of textual theory, this network of relations replaces the chain of signs mentioned by Saussure and Hjelmslev (see above: problem 8); the latter appears at most to be one specific reading with extremely limited differentiation. In this way, every discourse - and therefore every parole in Saussure's sense - reveals itself to be a whole conglomerate of texts.

\subsection{The subject}

To Saussure and Hjelmslev, senders and recipients of a discourse (i.e., the signinterpreters or subjects of semiosis) were only of interest insofar as they utilized codes and could turn them into discourse (cf. Jakobson 1960). This led to the perception beyond codes and the creativity of the subject being neglected and even denied (see above: dichotomy (d), problem 5). The subject appeared to be reduced to its function as the point where codes intersect. While Foucault and Baudrillard campaign against the submission of people to these codes by repudiating the code as fiction, Lacan (1966) takes the reduction of the subject even further. He tries to extinguish any remnants of a subject by claiming that we speak of a subject only at those points where we would otherwise encounter a gap in the chain of signifiers: the concept of the subject serves merely as a gap-filler and should be bypassed via a more thorough analysis of the chain of signifiers. Kristeva, too, intends to "pulverize" this kind of subject (Todorov and Ducrot 1972: 448). To this end she attempts a change of ontological categories and speaks of the subject merely as a meaning process (Harland 1987: 168). According to Derrida (1972) and de Man (1979), the subject is embodied in the multiplicity of his/her readings of a discourse, hence these authors' deci- 
sion to focus on this aspect. Barthes considers the subject to be tangible whenever the recipient surrenders him/herself to the images his/her own body generates while reading. This constitutes the "pleasure of the text" (Barthes 1973a).

\subsection{Semiotics}

By re-interpreting the basic structuralist categories, post-structuralism also changes ideas on what the tasks of semiotics should be. To Saussure and Hjelmslev, semiotics was the science of sign systems (see above: dichotomy (a), problems 1-3), whereas for post-structuralism it becomes the art of revealing or creating meaning in discourse. Semiotics becomes "semanalysis" (Kristeva 1969a) or the "deconstruction" of discourse (Derrida 1967a; de Man 1979, 1993; Culler 1982). An essential aid for the exercising of semiotics as an art is the ability to differentiate. This is a situation-dependent activity which can be practiced only when the material bases of semiosis are taken seriously. Post-structuralist semiotics in this sense is rightly considered "materialist gnoseology" (Todorov and Ducrot 1972: 452).

\section{Theses on the relations between structuralism and post-structuralism}

Attempting to summarize the essential points in the development of structuralism into post-structuralism, one arrives at the following theses:

Thesis 1:

Post-structuralism did not in fact take over from structuralism, rather it is part of its development and was put forward at the same time. The structuralists Greimas (1966), Prieto (1966, 1975), and Mounin $(1968,1970)$ published their most important works at the same time as Foucault, Althusser, Lacan, Derrida, Kristeva, and Baudrillard.

\section{Thesis 2:}

Post-structuralism does not overcome the paradoxes of structuralism, rather it displays them to their full extent and constantly plays one category off against the other. "[Post-structuralism] builds on top of the superstructuralist position more superstructurally than ever; it carries the same logic even further in the same direction. With post-structuralism, the old paradoxes are not dismantled but redoubled" (Harland 1987: 124).

Thesis 3:

Post-structuralism does not provide a new semiotic theory, rather it changes the focus of attention within the structuralist categories and relativizes certain 
concepts involved in Saussure's dichotomies. The main interest in semiotic studies is no longer the sign (the relation of signifier to signified) but semiosis (the process of creating meaning); it is no longer the paradigm (the relations between virtual signs) but the syntagm (the differences between signs in discourse); it is no longer the synchrony of a system of virtual signs (nor their diachrony), but intertextuality; it is no longer the code, but discourse.

Thesis 4:

This re-evaluation undermines the structuralist categories. Post-structuralists believe it possible to speak of signifiers without specifying signifieds, and to investigate signs without establishing a code. They reject basic theoretical distinctions and contaminate signals with signifiers, signifiers with signifieds, and signifieds with messages and referents.

Thesis 5:

While analytic philosophy in the wake of Peirce and Morris established pragmatic theories investigating principles and maxims which determine the interpretation of the sign in addition to code rules (Posner 1991), the poststructuralists tend to mix these two areas, using pragmatic principles and maxims to discredit code rules and vice versa.

Thesis 6:

Post-structuralism also rejects the distinction between the investigation and its object, between the processes of discourse analysis and the discourse being analyzed, between meta-text and text. In post-structuralist discourse analysis, scientific reflection and everyday behavior are deliberately mixed with the aim of freeing the latter of fictions and thus leading to change.

Thesis 7:

Post-structuralist discourse analysis is by its very nature not a science, but an art.

Only the future will show whether post-structuralism can achieve its aims with the tools at its disposal. It is worth mentioning, however, that the practice of post-structuralist discourse analysis well suits post-modern thinking, for several reasons. It subverts grand fictions and shatters their monopoly on reasoning. It integrates the remains of competing conceptions of humanity left after the failure of modernism such as psychoanalysis and political economy. Rather than making everyone wait for politicians and scientists to create a better future, as was often the case in modernism, post-structuralism encourages every individual to test the possibilities for improving his or her own state.

It must be noted that post-modern mediation between distinct discourses has been applied in post-structuralism more to the various discourses of everyday life than to those of the arts and sciences. For semiotics one can diagnose a 
convergence of post-structuralism with Peircean pragmaticism, both trying to demonstrate how it is possible to get along without code-fictions. However, other traditions, more closely geared towards the social sciences, have continued to develop more or less independently of post-structuralist thinking, such as:

- biosemiotics, which now links genetic code theory to ethology and ecology (cf. Sebeok and Umiker-Sebeok 1992);

- computer semiotics, which connects the theory of sign processes in machines with various approaches to Artificial Intelligence research (cf. Andersen 1990; Jorna et al. 1993);

- semiotics of traffic systems, mass media, and communication networks (cf. Sless 1978; Rogers and Kinhaid 1981; Bijker et al. 1987; Hawkins et al. 1988; Posner 1985, 1995).

Therefore, there clearly is a future for semiotics after post-structuralism. It comes as no surprise that many post-structuralists reject this type of semiotics as irrelevant. Roland Barthes, for example, wrote in the introduction to the English version of Eléments de sémiologie:

It is far from certain that in the social life of today there are to be found any extensive systems of signs outside human language. Semiology has so far concerned itself with codes of no more than slight interest, such as the Highway Code; the moment we go on to systems where the sociological significance is more than superficial, we are at once confronted with language. (Barthes 1968: 9-10)

It seems an irony of fate that Barthes eventually died in a traffic accident. David Sless comments on this tragic event by asking: "Was his death the result of semiotic transgression? Was he cut down because of an infringement of a code of slight interest with only superficial sociological significance?” (1986: 148).

\section{Notes}

* An earlier version of this article appeared in English in Norma A. Tasca (ed.), Ensaios em homenagem a / Essays in Honor of Thomas A. Sebeok (= Cruzeiro Semiótico 22-25), Porto, 1995: 51-73; the German version was published in 1993 under the title "Semiotik diesseits und jenseits des Strukturalismus: Zum Verhältnis von Moderne und Postmoderne, Strukturalismus und Poststrukturalismus" in Zeitschrift für Semiotik 15(3/4), 211-233.

1. Controversies regarding the beginnings of the Modern Age, some of which reach back to the Enlightenment or Renaissance, cannot be investigated here (but cf. Welsch 1987, 1991; Habermas 1990; Kondylis 1991).

2. For a list of these authors' major works and their place in history, see Posner (1984).

3. For a definition of "structure," see Wunderlich (1971), Posner (1986: 1045-1047), and Albrecht (2000: 225-245). 
4. For the historical references to Nietzsche and Valéry bound up in the phrase tel quel ('as it is'), cf. Kauppi (1994: 27).

5. This calls to mind a poem by Charles Morris, published around the same time, called Scientia, where such things are said not about texts, but about science: "Science deepens all our surfaces / Yet it is but one surface of our depths" (cf. Posner 1981: 84).

6. See the oft-cited assertion by Peirce ( $C P$ 2.300): "[A sign is] anything which determines something else (its interpretant) to refer to an object to which itself refers (its object) in the same way, this interpretant becoming in turn a sign, and so on ad infinitum." See Eco's commentary on similar thoughts as expressed by Derrida (1967a) in Eco (1990: 34-43).

\section{References}

Albrecht, Jörn. 2000. Europäischer Strukturalismus: Ein forschungsgeschichtlicher Überblick. 2nd edn. Tübingen: A. Francke Verlag.

Althusser, Louis. 1965a. Pour Marx. Paris: François Maspero.

Althusser, Louis. 1965b. Lire le Capital. Paris: François Maspero.

Althusser, Louis. 1970. Idéologie et appareils idéologiques d'etat. La pensée 151. 3-38.

Andersen, Peter B. 1990. A theory of computer semiotics: Semiotic approaches to construction and assessment of computer systems. Cambridge, MA: Cambridge University Press.

Bakhtin, Michail M. 1929. Problemy tvorchestva Dostoyevskogo. Leningrad.

Bakhtin, Michail M. 1965. Tvorchestvo Fransua Rabele i narodnaya kultura sreddevekovya i renessansa. Moscow.

Bakhtin, Michail M. 1981. The dialogic imagination: Four essays, C. Emerson \& M. Holquist (trans. and ed.). Austin: University of Texas Press.

Barthes, Roland. 1964. Eléments de sémiologie. Communications 4. 91-135.

Barthes, Roland. 1966. Introduction à l'analyse structurale du récit. Communications 8. 1-27.

Barthes, Roland. 1968. Elements of semiology. New York: Hill and Wang.

Barthes, Roland. 1970. S/Z. Paris: Seuil.

Barthes, Roland. 1973a. Le plaisir du texte. Paris: Seuil.

Barthes, Roland. 1973b. Théorie du texte. In Encyclopaedia Universalis, vol. 15, 1014-1017. Paris: Encyclopaedia Universalis.

Barthes, Roland. 1979. Sollers écrivain. Paris: Seuil.

Baudrillard, Jean. 1968. Le système des objects. Paris: Gallimard.

Baudrillard, Jean. 1972. Pour une critique de l'économie politique du signe. Paris: Gallimard.

Baudrillard, Jean. 1973. Le miroir de la production. Paris: Gallimard.

Baudrillard, Jean. 1976. L'échange symbolique et la mort. Paris: Gallimard.

Berlin, Brent \& Paul Kay. 1969. Basic color terms. Berkeley: University of California Press.

Bijker, Wiebe E., Thomas P. Hughes \& Trevor J. Pinch. 1987. The social construction of technological systems. Cambridge: MIT Press.

Calinescu, Matei. 1987. Five faces of modernity: Modernism, avant-garde, decadence, kitsch, postmodernism. Durham: Duke University Press.

Coseriu, Eugenio. 1981. Lecciones de lingüistica general. Madrid: Gredos.

Culler, Jonathan. 1981. The pursuit of signs: Semiotics, literature, deconstruction. Ithaca: Cornell University Press.

Culler, Jonathan. 1982. On deconstruction: Theory and criticism after structuralism. Ithaca: Cornell University Press.

Davies, Alistair. 1982. An annotated critical bibliography of modernism. Brighton: Harvester Press. 
Deleuze, Gilles \& Félix Guattari. 1972. Capitalisme et schizophrénie. Paris: Minuit.

Deleuze, Gilles \& Félix Guattari. 1976. Rhizome. Paris: Minuit.

Derrida, Jacques. 1967a. L'écriture et la différence. Paris: Seuil.

Derrida, Jacques. 1967b. De la grammatologie. Paris: Seuil.

Derrida, Jacques. 1967c. La voix et le phénomène. Paris: PUF.

Derrida, Jacques. 1972. La dissémination. Paris: Seuil.

Eco, Umberto. 1967. Opera aperta. Milan: Bompiani.

Eco, Umberto. 1968. La struttura assente. Milan: Bompiani.

Eco, Umberto. 1976. A theory of semiotics. Bloomington: Indiana University Press.

Eco, Umberto. 1990. The limits of interpretation. Bloomington: Indiana University Press.

Eismann, Wolfgang \& Peter Grzybek. 1994. In memoriam Jurij Michajlovic Lotman (1922-1933).

Zeitschrift für Semiotik 16. 105-116.

Even-Zohar, Itamar. 1983. Kodewandel und Sinnentleerung. Zeitschrift für Semiotik 5. 63-74.

Fokkema, Douwe \& Elrud Ibsch. 1987. Modernist conjectures: A mainstream in European Literature 1910-1940. London: Hurst.

Forster, Hal (ed.). 1985. Postmodern culture. London: Pluto Press.

Foucault, Michel. 1961. Folie et déraison: Histoire de la folie à l'âge classique. Paris: Plon.

Foucault, Michel. 1966. Les mots et les choses. Paris: Gallimard.

Foucault, Michel. 1969. L'archéologie du savoir. Paris: Gallimard.

Frank, Manfred. 1986. Was ist Neostrukturalismus? Frankfurt a. M.: Suhrkamp.

Frühwald, Wolfgang et al. 1991. Geisteswissenschaften heute: Eine Denkschrift. Frankfurt a. M.: Suhrkamp.

Giddens, Anthony. 1990. The consequences of modernity. Stanford: Stanford University Press.

Greimas, Algirdas J. 1966. Sémantique structurale. Paris: Larousse.

Guggenberger, Bernd, Dieter Janson \& Joachim Leser (eds.). 1992. Postmoderne oder das Ende des Suchens? Eine Zwischenbilanz. Eggingen: Isele.

Gumbrecht, Hans Ulrich. 1988. Rhythmus und Sinn. In Hans Ulrich Gumbrecht \& Karl Ludwig Pfeiffer (eds.), Materialitäten der Kommunikation, 914-929. Frankfurt a. M.: Suhrkamp.

Gumbrecht, Hans Ulrich \& Robert Weimann (eds.). 1991. Postmoderne - globale Differenz. Frankfurt a. M.: Suhrkamp.

Habermas, Jürgen. 1990. Die Moderne - ein unvollendetes Projekt. Leipzig: Reclam.

Happ, Heinz. 1985. "paradigmatisch" - "syntagmatisch": Zur Bestimmung und Klärung zweier Begriffe der Sprachwissenschaft. Heidelberg: Winter.

Harland, Richard. 1987. Superstructuralism: The philosophy of structuralism and poststructuralism. London: Methuen.

Harland, Richard. 1993. Beyond superstructuralism: The syntagmatic side of language. London: Routledge.

Hartman, Geoffrey. 1980. Criticism in the wilderness. New Haven: Yale University Press.

Hassan, Ihab. 1987a. The postmodern turn: Essays in postmodern theory and culture. Columbus: Ohio State University Press.

Hassan, Ihab. 1987b. Pluralism in postmodern perspective. In Matei Calinescu \& Douwe Fokkema (eds.), Exploring postmodernism, 17-39. Amsterdam: Benjamins.

Hawkins, Robert, John M. Wiemann \& Suzanne Puingree (eds.). 1988. Advancing communications science: Merging mass and interpersonal processes. Newbury Park: Sage.

Heath, Stephen, Colin MacCabe \& Christopher Prendergast (eds.). 1971. Signs of the times: Introductory readings in textual semiotics. Cambridge: Granta.

Hjelmslev, Louis. 1963. Prolegomena to a theory of language, $2^{\text {nd }}$ edn. Madison: University of Wisconsin Press.

Hjelmslev, Louis. 1973. The basic structure of language. In Essais linguistiques II, 119-153. Copenhagen: Nordisk Sprog- og Kulturforlag. 
Hörmann, Hans. 1976. Meinen und Verstehen: Grundzüge einer psychologischen Semantik. Frankfurt a. M.: Suhrkamp.

Irigaray, Luce. 1974. Speculum, de l'autre femme. Paris: Minuit.

Jakobson, Roman. 1960. Linguistics and poetics. In Style in language, Thomas A. Sebeok (ed.), 350-377. Cambridge, MA: MIT Press.

Jencks, Charles. 1984. The language of post-modern architecture. New York: Academy Editions.

Jorna, René, Barend van Heusden \& Roland Posner (eds.). 1993. Signs, search, and communication: Semiotic aspects of artificial intelligence. Berlin: Walter de Gruyter.

Kamper, Dietmar \& Willem van Reijen (eds.). 1987. Die unvollendete Vernunft: Moderne versus Postmoderne. Frankfurt a. M.: Suhrkamp.

Kauppi, Niilo. 1994. The making of an avant-garde: Tel quel. Berlin/New York: Mouton de Gruyter.

Keupp, Heiner. 1993. Grundzüge einer reflexiven Sozialpsychologie: Postmoderne Perspektiven. In H. Keupp (ed.), Zugänge zum Subjekt: Perspektiven einer reflexiven Sozialpsychologie, 226274. Frankfurt a. M.: Suhrkamp.

Klotz, Heinrich. 1984. Moderne und Postmoderne: Architektur der Gegenwart 1960-1980. Braunschweig: Vieweg.

Knorr-Cetina, Karin. 1981. Manufacture of knowledge: Essay on the constructivist and contextual nature of science. New York: Pergamon.

Knorr-Cetina, Karin. 1991. Die Fabrikation von Erkenntnis: Zur Anthropologie der Naturwissenschaft. Frankfurt a. M.: Suhrkamp.

Köhler, Michael. 1977. "Postmodernismus": Ein begriffsgeschichtlicher Überblick. AmerikaStudien 22. 8-18.

Köster, Lothar. 1994. Von Saussure zum Konnektionismus: Struktur und Kontinuität in der Lexemsemantik und der Musiksemiotik. Wiesbaden: DUV.

Kondylis, Panajotis. 1991. Der Niedergang der bürgerlichen Denk- und Lebensform: Die liberale Moderne und die massendemokratische Postmoderne. Weinheim: VCH, Acta Humaniora.

Koslowski, Peter. 1987. Die postmoderne Kultur: Gesellschaftlich-kulturelle Konsequenzen der technischen Entwicklung. Munich: Beck.

Kristeva, Julia. 1969a. Semeiotiké: Recherches pour une sémanalyse. Paris: Seuil.

Kristeva, Julia. 1969b. Narration et transformation. Semiotica 1. 422-448.

Kristeva, Julia. 1970. Le texte du roman. Approche sémiologique d'une structure discursive transformationnelle. The Hague: Mouton.

Kristeva, Julia. 1974. Pratique signifiante et mode de production. Tel Quel 60. 21-33.

Lacan, Jacques. 1966. Écrits. Paris: Seuil.

Lather, Patti. 1990. Postmodernism and the human sciences. Humanistic Psychologist 18. 64 84.

Lethen, Helmut. 1970. Neue Sachlichkeit 1924-1932: Studien zur Literatur des “weißen Sozialismus. " Stuttgart: Metzler.

Lévi-Strauss, Claude. 1958. Anthropologie structurale. Paris: Plon.

Loo, Hans van der \& Willem van Reijen (eds.). 1992. Modernisierung: Projekt und Paradox, Marga E. Baumer (trans.). Munich: dtv.

Lotman, Yuri M. 1977. Kultura kak kollektivnyi intellekt i problemy iskusswennogo razuma (Culture as collective intellect and problems of artificial intelligence). Moscow: Akademija Nauk SSSR.

Lotman, Yuri M. 1981. Kunst als Sprache: Untersuchungen zum Zeichencharakter von Literatur und Kunst, Klaus Städtke (ed.). Leipzig: Reclam.

Lotman, Yuri M. 1992. Kultura i vzryv (Culture and explosion). Moscow: Gnozis.

Lotman, Yuri M. 2001. Universe of the mind: A semiotic theory of culture, Ann Shukman (trans.). London: I. B. Tauris. 
Lützeler, Paul Michael. 1991. Einleitung: Von der Spätmoderne zur Postmoderne. In P. M. Lützeler (ed.), Spätmoderne und Postmoderne: Beiträge zur deutschsprachigen Gegenwartsliteratur, 11-22. Frankfurt a. M.: Fischer.

Lyotard, Jean-François. 1979. La condition postmoderne: Rapport sur le savoir. Paris: Minuit.

Man, Paul de. 1979. Allegories of reading: Figural language in Rousseau, Nietzsche, Rilke, and Proust. Providence, RI: Yale University Press.

Man, Paul de. 1993. Die Ideologie des Ästhetischen, Jürgen Blasius (trans.), Christoph Menke (ed.). Frankfurt a. M.: Suhrkamp.

Mey, Jacob. 1993. Pragmatics: An introduction. Oxford: Blackwell.

Mounin, Georges. 1968. Saussure ou le structuralisme sans le savoir. Paris: Seghers.

Mounin, Georges. 1970. Introduction à la sémiologie. Paris: Minuit.

Niethammer, Lutz. 1989. Posthistoire: Ist die Geschichte zu Ende? Reinbek: Rowohlt.

Odgen, Charles K. \& Ivor A. Richards. 1923. The meaning of meaning: A study of the influence of language upon thought and of the science of symbolism. London: Routledge.

Pêcheux, Michel. 1975. Les vérités de la palice. Paris: Maspero.

Peirce, Charles S. 1931-1966. The collected papers of Charles S. Peirce, 8 vols., C. Hartshorne, P. Weiss \& A. W. Burks (eds.). Cambridge: Harvard University Press. [Reference to Peirce's papers will be designated $C P$ followed by volume and paragraph number.]

Pocheptsov, Georgij. 1993. Neuere Überlegungen Lotmans zur Zeichendynamik. Zeitschrift für Semiotik 15. 345-351.

Posner, Roland. 1981. Charles W. Morris und die verhaltenstheoretische Grundlegung der Semiotik. In M. Krampen, K. Oehler, R. Posner \& T. von Uexküll (eds.), Die Welt als Zeichen: Klassiker der modernen Semiotik, 51-98. Berlin: Severin und Siedler.

Posner, Roland. 1984. Vom Russischen Formalismus zur Glossematik: Europäische Semiotiker der Zwischenkriegszeit. Zeitschrift für Semiotik 6. 383-396.

Posner, Roland. 1985. Zur Systematik der Beschreibung verbaler und nonverbaler Kommunikation: Semiotik als Propädeutik der Medienanalyse. In Hans-Georg Bosshardt (ed.), Perspektiven auf Sprache: Interdisziplinäre Beiträge zum Gedenken an Hans Hörmann, 267-313. Berlin: Walter de Gruyter.

Posner, Roland. 1986. Syntactics. In Thomas A. Sebeok (ed.), Encyclopedic dictionary of semiotics, 1042-1061. Berlin/New York: Walter de Gruyter.

Posner, Roland. 1987. Charles W. Morris and the behavioral foundations of semiotics. In Martin Krampen et al. (eds.), Classics of semiotics, 23-58. New York: Plenum.

Posner, Roland. 1988. The epistemological status of semiotics and the task of a semiotic handbook: Eight theses. In Amy Mandelker, Thomas Ekman, Roland Posner \& Edward Stankiewicz (eds.), Semiotics and the arts: Festschrift in Honor of T. G. Winner, 125-130. San Diego: Charles Schlacks.

Posner, Roland. 1989. What is culture? Toward a semiotic explication of anthropological concepts. In Walter A. Koch (ed.), The nature of culture, 240-295. Bochum: Brockmeyer.

Posner, Roland. 1991. Research in pragmatics after Morris. Dedalus 1. 115-156.

Posner, Roland (ed.). 1995. Kommunikation im Straßenverkehr. Special issue of Zeitschrift für Semiotik 17(1/2).

Prieto, Luis J. 1966. Messages et signaux. Paris: PUF.

Prieto, Luis J. 1975. Pertinence et pratique: Essai de sémiologie. Paris: Minuit.

Ricoeur, Paul. 1969. Le conflit des interprétations: Essais d'herméneutique. Paris: Seuil.

Ricoeur, Paul. 1976. Interpretation theory: Discourse and the surplus of meaning. Fort Worth: Texan Christian University Press.

Riffaterre, Michael. 1978. Semiotics of poetry. Bloomington: Indiana University Press.

Rogers, Everett M. \& D. Lawrence Kincaid. 1981. Communication networks: Toward a new paradigm for research. New York: Free Press. 
Rommetveit, Ragnar. 1974. On message structure: A framework for the study of language and communication. London: Wiley.

Rommetveit, Ragnar. 1984. In search of a truly interdisciplinary semantics: A sermon on hopes of salvation from hereditary sins. Journal of Semantics 2. 1-28.

Rorty, Richard. 1979. Philosophy and the mirror of nature. Princeton: Princeton University Press. Saussure, Ferdinand de. 1950. Course in general linguistics, Wade Baskin (trans.). London: Peter Owen.

Schiwy, Günther. 1985. Poststrukturalismus und "Neue Philosophen.” Reinbek: Rowohlt.

Schlieben-Lange, Brigitte. 1993. Einleitung: Materiale Bedingungen der Sprach- (und Literatur-) wissenschaft. Zeitschrift für Literaturwissenschaft und Linguistik 90-91. 7-22.

Sebeok, Thomas A. \& Jean Umiker-Sebeok (eds.). 1992. Biosemiotics: The semiotic web 1991. Berlin: Mouton de Gruyter.

Sless, David. 1978. Visual thinking. Adelaide: Adelaide University Press.

Sless, David. 1986. In search of semiotics. London: Croom Helm.

Sperber, Dan \& Deirdre Wilson. 1986. Relevance: Communication and cognition. Oxford: Blackwell.

Stephens, Mitchell. 1994. Jacques Derrida. New York Times Magazine, 23 January. 22-25.

Stierle, Karlheinz. 1979. Altertumswissenschaftliche Hermeneutik und die Entstehung der Neuphilologie. In Hellmut Flashar, Karlfried Gründer \& Axel Horstmann (eds.), Philologie und Hermeneutik im 19. Jahrhundert: Zur Geschichte und Methodologie der Geisteswissenschaften, 260-288. Göttingen: Vandenhoeck \& Ruprecht.

Tepe, Peter. 1992. Postmoderne, Poststrukturalismus. Vienna: Passagen.

Todorov, Tzvetan. 1981. Mikhail Bakhtine: Le principe dialogique suivi des Ecrits du Cercle de Bakhtine. Paris: Seuil.

Todorov, Tzvetan \& Oswald Ducrot. 1972. Dictionnaire encyclopédique des sciences du langage. Paris: Seuil.

Welsch, Wolfgang. 1987. Unsere postmoderne Moderne. Weinheim: VCH Acta humaniora.

Welsch, Wolfgang. 1991. Rückblickend auf einen Streit, der ein Widerstreit bleibt — Noch einmal: Moderne versus Postmoderne. Initial 4. 341-351.

Wunderlich, Dieter. 1971. Terminologie des Strukturbegriffs. In Jens Ihwe (ed.), Literaturwissenschaft und Linguistik: Ergebnisse und Perspektiven. Bd. I: Grundlagen und Voraussetzungen, 91-140. Frankfurt a. M.: Athenäum.

Young, Robert. 1981. Post-structuralism: An introduction. In R. Young (ed.), Untying the text: A post-structuralist reader, 1-28. London: Routledge.

Zacharias, Thomas. 1984. Blick der Moderne: Einführung in ihre Kunst. Munich: Schnell \& Steiner.

Roland Posner (b. 1942) is Professor emeritus of linguistics and semiotics and Director of the Research Center for Semiotics (RCS) at the Technische Universität Berlin. His research interests include linguistic progmatics, semiotics of culture, and philosophy of science. His publications include Theorie des Kommentierens (1972, 2nd edition 1980), Rational Discourse and Poetic communication (1982), "Believing, causing, intending: The basis for a hierarchy of sign concepts in the reconstruction of communication" in René Jorna et al. (eds.), Signs, Search and Communication: Semiotic Aspects of Artificial Intelligence (1993), and "The metropolis as a giant hall of mirrors" in Daina Teters (ed.), Metamorphoses of the World (2010). From 1994 until 2004, Roland Posner was President of the International Association for Semiotic Studies (IASS), of which he is now Honorary President; see www.semiotik.tu-berlin.de. 